\title{
Towards Family Economic Sustainability: The Transformation of Traditional Sulphur Miners in Ijen Crater
}

\author{
Alfiana Yuli Efiyanti ${ }^{*}$, Aliya Fatimah $^{2}$ \\ ${ }^{1}$ Universitas Islam Negeri Maulana Malik Ibrahim, Malang \\ ${ }^{2}$ Universitas Bakti Indonesia, Banyuwangi \\ 2alfi_huda@pips.uin-malang.ac.id
}

\begin{abstract}
Sulphur miners in Ijen crater, Banyuwangi, Indonesia has been undergoing life changing experience for many years. It happened due to the natural phenomena of the area. Mount Ijen has a potential natural tourism that might attract domestic and international tourists. In addition, the area has high sulphur contents. The management of sulphur is fully authorized by CN Company. The traditional miners deposit the mining results to the company. Working in sulphur mining is very risky, especially for the carriers who are paid based on the quantity of sulphur they bring up from the crater. This study explores in deep the profile of the traditional sulphur miners in Ijen crater, Banyuwangi. It employs a qualitative approach to obtain the real image of their profile. The research results are (1) three types of traditional sulphur miners in Ijen crater are found. Two of them are permanent employees of the company while the remaining type of the miners is independent worker, whose activities are searching and carrying the sulphur. The Ijen crater miners had an uncertain income, depending on the amount of sulphur successfully transported. (2) The minimum income of the traditional miners leads them to transform the job into businesses. (3) The transformation lets them contribute more to their family life.
\end{abstract}

Keywords

Traditional Sulphur Miners, Ijen crater, Family Economic Sustainability.

Article Received: 10 August 2020, Revised: 25 October 2020, Accepted: 18 November 2020

\section{Introduction}

Mount Ijen, located in Banyuwangi, Indonesia, is one of the national tourism icons. This mountain is famous with the beauty of the contours in the top and the crater that serves a natural phenomenon of blue fire. The amazing blue fire appeared due to the high content of sulphur inside the crater of Mount Ijen. The natural wealth inside remarkably attracts local and international tourists.

Besides the potential tourism, Ijen crater is a sulphur producer in Indonesia with the highest production compared with other regions. It can produce up to fourteen (14) tons of sulphur every day. It is only about $20 \%$ of the real potential of the nature. Sulphur is generally used for sugar whitener [1].

The processing and utilization of sulphur in Indonesia has been set since 1911 in the Dutch colonial era. Since 1970, sulphur processing from the crater has been made. Sulphur has been managed by a single company, Argo company that turns into $\mathrm{CN}$ company. The company is located in the subdistrict of Licin village, the distance is fifteen (15) $\mathrm{km}$ from the crater of Mount Ijen.
The mining and transport of sulphur in Ijen crater are traditionally held without technology support. The process to get the sulphur from the crater involves a lot of human labors as miners. Some of the miners are permanent employees of $\mathrm{CN}$ company, and some are traditional miners without company work contracts. The permanent employees work at the crater as the Superintendent of Sulfatara (SS) and some work in the sulphur burning division in the processing area.

Whilst, the traditional miners, who are not under the company contract, seek and carry the sulphur from the crater of Mount Ijen to the location in which they can weigh and sell it to the company. The traditional miners and carriers of sulphur use traditional protective equipment upon working. They earn wages based on the quantity of sulphur successfully retrieved from the bottom of the crater.

Fatimah [3] stated that: "The three types of the miners, the carriers' income is uncertain, depending on the amount of sulphur carried from the bottom of the crater. Even though they have been working optimally, the income of the miners is not comparable with their risks. Their income 
can only meet their daily basic needs. The traditional miner, the non-permanent one, is the main focus of the current study."

The low income of the traditional miners pushes them to improve the standard of living. Some of the miners begin to think about the future of their children in order not to live a difficult life as they have experienced. Thus, since 2013, some miners have started to transform their job. They no longer rely on sulphur mining. They begin to think about other ways to earn money by making the most of the natural potential of Mount Ijen. The transformation is carried out by slowly reducing the work volume little by little. They could not completely leave the job because they have already been merged with nature. They slowly transform their job to businesses such as providing homestay for tourists, becoming a tour guide, raising Etawa goat milk and cultivate the catfish.

The transformation of the traditional miners has unconsciously increased the economic sustainability. Basically, sustainable economy is one of the pillars of sustainable development. Sustainable development is dependent upon the balance of three pillars: environmental, social, and economic sustainability. Environmental sustainability focuses on the maintenance of the nature while social sustainability pays more attention on the society rights and equality. The economic sustainability concerns on the society income and standard of living.

This research explores in depth the dynamics of the lives of the traditional sulphur miners, so they transform the livelihood into businesses. The research focuses on three important things to obtain the overall picture of the problems, including: (1) the life profile of traditional sulphur miners, (2) the transformation process of the traditional sulphur miners, and (3) the family economic sustainability of the sulphur miners after the transformation.

\section{LITERATURE STUDY}

The data are linked and communicated with various relevant literatures to sharpen the analysis. Some reviews of the literature are presented in the following section.

\section{Traditional Miner}

Traditionally miner refers to the workers who do the mining using simple tools such as shovels, hoes, pickaxe, and so on. They are commonly local societies around the mining area. They usually create small groups to ease the work. The results of the mining are collected and sold to the mining company.

Mochammad Aziz [5] stated that: "The traditional gold miners in Banyumas, does not write the workers as the traditional miners but a community miners or local miners. On the other side, the activities of natural resource management by the communities often lead to distorted image on the role of society on the mining management. It affords to involve society in the management of mining, which must be supported by all parties to create society independence in a business. Furthermore, he also emphasizes that the local miners still cannot provide significant revenue to the local government and the society. Therefore, it needs a serious concern."

\section{Sustainable Development}

Sustainable Development has been defined by many experts, so Mensah and Casadevall simplify the term through a research review of literature, combining Preferred Reporting Items for Systematic Reviews and Meta-Analyses (PRISMA) and Recursive Content Abstraction (RCA) approach. It concludes that Sustainable Development has three pillars, including: environment, social, and economy [4], [6], [7].

\section{Family Economic Sustainability}

Family economic sustainability is one of the important things to support the realization of sustainable development because family is the most fundamental unit in the social order [7]. Thus, family can contribute to the sustainable macro economy. Hawkins states that personal and family sustainability can be seen as maximizing full human potential to establish long-term economic, physical, psychological, and social well-being for individuals and their families [9].

\section{RESEARCH METHODS}

This research observed the lives of traditional sulphur miners in Ijen crater, Banyuwangi, Indonesia. The research method used a qualitative approach to obtain a clear, detail, and thorough pictures about the phenomena. The objective of this research is to identify the experiences of the subjects upon living as traditional miners and their transformation process [8], [9]. There are five 
traditional sulphur miners who do the transformation work subjected as key informants. While the secondary informants, who provide additional data, are the other traditional miners, the employees and the managers of CN Company (Sulphur Processing), and the regional government of Banyuwangi.

Data are collected by using thorough observation techniques, in-depth interviews with the informants, and deep study on the supporting documents. Data are naturally collected where the researcher lives and blends with the subjected societies for approximately twenty four (24) months. The area perceived to provide accurate data is Licin Village. The collected data are then analyzed through data reduction and classification, by which conclusion is made.

\section{RESULTS AND DISCUSSION}

\section{The Profile of the Traditional Sulphur Miners' Life}

Khoiriyah, and Harini [2] stated that: "There are three types of workers referred to a sulphur miner in Ijen crater. The first is the SS. SS are permanent employees of CN company, who officially work in the areas of mining in the bottom of the crater of Mount Ijen, or commonly called Pawon." Their job is to install pipes that serve as a way to drain the fluid or molten sulphur. Besides, they do watering the pipes so that the temperature remains normal. They are usually appointed as permanent employees after they have worked as sulphur carriers for more than 9 years. However, to gain more income, many of them do additional work as carriers when they're not on working schedule."

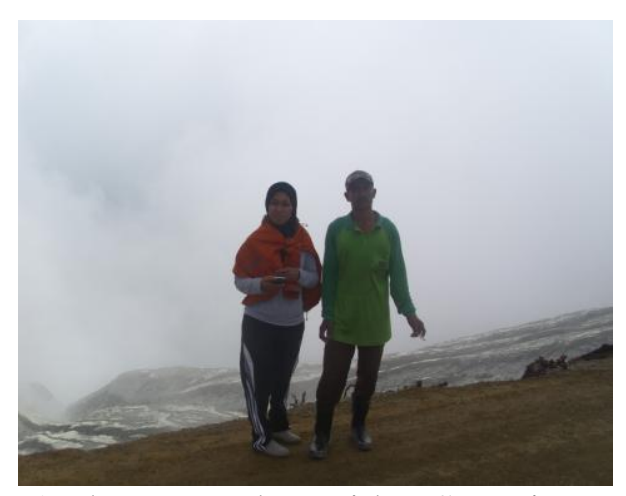

Figure. 1 The researcher with a Superintendent of Sulfatara (SS)
The second type of the miner serves in the sulphur combustion division. The burning location is not far from $\mathrm{CN}$ company. The miners working in the division of combustion or processing of sulphur is not easy although the accident risk is not as high as that of the miners who work directly in the crater. Those who work in the sulphur burning division are at risk of respiratory health. All employees who work at burning division have previously been the carriers of the sulphur at least ten (10) years.

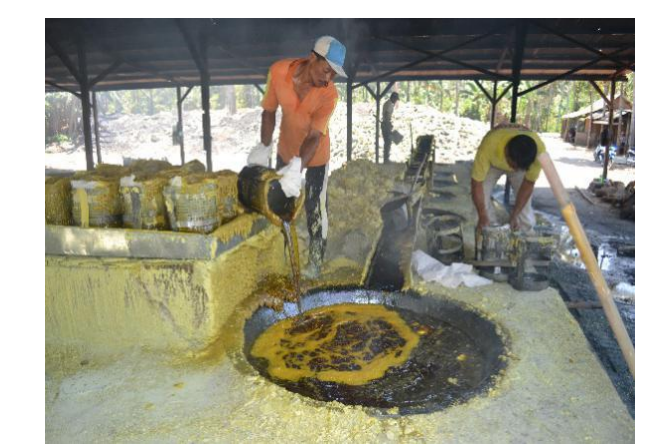

Figure 2. The miners who work in the area of sulphur burning.

The third type of the miner is the sulphur carrier. This work is much more demanded by people around Mount Ijen because the wages can be directly received right after the sulphur is delivered. Besides, working as a carrier of sulphur does not require a high education. Anyone could be a carrier of sulphur as long as he is a physically strong. The age of the miners ranged from 15 to 64 years old. The traditional miners are generally able to bear $40-90 \mathrm{~kg}$ Sulphur per day. The selling price of the sulphur to the company in 2015 was around USD $0.065-$ USD 0.072 per $\mathrm{kg}$, and the price increased to USD 0.09 per $\mathrm{kg}$ in 2020. How to increase their income? The miner has to carry two to three times a day depending on their physical strength.

The process of mining and transportation of sulphur uses traditional methods. The miners must hike to the peak of Mount Ijen with an altitude of 3,450 meter above the sea level with a distance of eight (8) $\mathrm{km}$ from the slopes of the mountain to reach the bottom of the crater. The miners go down from the top of the mountain through steep cliffs heading to the location of sulphur mining. The sulphur is then collected with simple tools such as hoes and pickaxes. The miners used the bamboo basket and resisting wood, the sulphur is carried up the mountain and down until they reach 
the sulphur weighing location at the foot of the mountain. Some miners use wheelbarrows as the sulphur transportation facility (see Figure 3).

The three types of the miners have a severe risk to health and safety. However, the risk of unsustainable economy of the family is heavier for the sulphur carriers considering they do not have a fixed income. If the miners are experiencing health problems or are having another business, then they do not do mining, he and his family may not make income on that day. It happens also when the miners grow old that they cannot work again. Whereas, the economic sustainability of the family is very important for their childrens

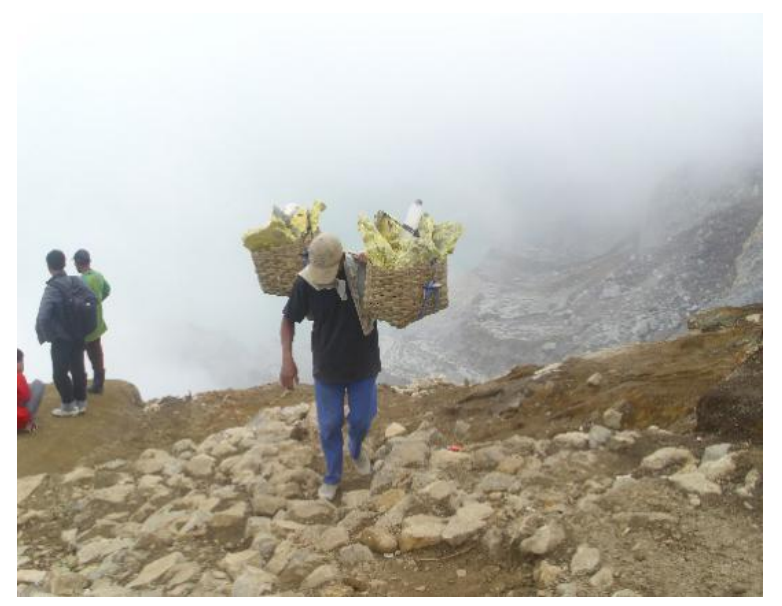

Figure 3. The miners who carry the sulphur future [10].

Table 1. The Profile of the Traditional Miners

The profiles of the sulphur miners are briefly described in the following table:

\begin{tabular}{|c|c|c|c|}
\hline \multirow[t]{2}{*}{ Types of Miners } & \multirow[t]{2}{*}{ Job Status } & \multirow[t]{2}{*}{ Health and safety risks } & \multirow{2}{*}{$\begin{array}{l}\text { The Risk } r \text { of } \\
\text { Unsustainable } \\
\text { Economy }\end{array}$} \\
\hline & & & \\
\hline $\begin{array}{l}\text { Superintendent } \\
\text { of Sulfatara (SS) }\end{array}$ & $\begin{array}{l}\text { Permanent } \\
\text { employees } \\
\text { of CN Co. }\end{array}$ & $\begin{array}{l}\text { Exposed directly by sulphur } \\
\text { from the source. } \\
\text { The risk of accidents down to } \\
\text { the job site at the base of the } \\
\text { crater because they have to } \\
\text { take the rugged and steep } \\
\text { terrain }\end{array}$ & - \\
\hline Sulphur Burners & $\begin{array}{l}\text { Permanent } \\
\text { employees } \\
\text { CN Co. }\end{array}$ & $\begin{array}{l}\text { Exposed to the sulphur } \\
\text { smoke during the burning } \\
\text { process. }\end{array}$ & $\begin{array}{l}\text { At risk of respiratory } \\
\text { health- }\end{array}$ \\
\hline Sulphur Carriers & Independent & $\begin{array}{l}\text { Exposed directly by sulphur } \\
\text { from the source. } \\
\text { The risk of accidents down to } \\
\text { the job site at the base of the } \\
\text { crater because they have to } \\
\text { take the rugged and steep } \\
\text { terrain carrying the sulphur. }\end{array}$ & $\begin{array}{l}\text { If the miner is not able to } \\
\text { work due to certain } \\
\text { unexpected business, the } \\
\text { miners and their families } \\
\text { do not earn income at all. }\end{array}$ \\
\hline
\end{tabular}

\section{The Transformation of the Traditional Sulphur Miners}

Since 2000, the sulphur miners began to shift their thinking, especially the young ones. They start thinking about the possibility and opportunity of another job because they concern about the unattainable need for their children's education due to the low income as miners. They hope the children have a better job along with the good education. The less adequate income leads the miners to shift their livelihood.

There are a wide variety of work opportunity expected to increase their revenue in addition to working as a miner along with the skill they have. Adjusting with the nature and the potential around the area of Mount Ijen, there are four types of work carried out by the miners during the transformation process: 


\section{Transforming to be tour guides}

The transformation from sulphur miners to the tour guide is done part time in the beginning. When few tourists visit the area of Mount Ijen, the miners go on with mining. When many tourists visit the area, the miners turned to be tour guides. As tourist guides, they earn greater income with a lighter work burden. The miners who shift into tour guide also face the challenge when the tourists are from other countries. They have to learn foreign languages especially English to facilitate communication at work. They are also trying to increase the knowledge about tourism to serve the tourists well. Thus, being a tourist guide may motivate the miners to keep learning. Their interest to work as a tour guide is more preferable. The data show that until the end of 2019, the miners who turn to be tour guides have completely left their job as miners.

\section{Transforming to be homestay providers}

The natural beauty of Ijen crater attracts the tourists to enjoy the place longer, not just climbing the peak. A lot of tourists also want to blend with the natural life of the village. Homestays around the tourist locations are highly demanded. The miners who have houses in the villages around the slopes of Mount Ijen take most of this situation by transforming to be homestay providers. They can get higher income with this transformation. Providing a homestay is necessarily equipped with various other skills, such as communication skills, management skills, and skills in terms of sanitation to keep the environment clean and healthy. The learning process of the miners continues through the new experience. The success in providing homestay finally lets a lot of miners leave their work.

\section{Transforming to other jobs outside mining}

The natural resources around the area of Mount Ijen provides a lot of business opportunities. Some miners do fisheries and animal husbandry such as catfish and goat. They generally run the business under the assistance of the Department of Fisheries and Animal Husbandry. Some also do business in construction, such as producing concrete bricks. The data shows that the businesses in animal husbandry are not successful due to various causes. They are 1) lack of knowledge and skill of the miners in the field of animal husbandry and fisheries, 2) the habit for many years that the miners received a direct pay right after the work while fish and goat farming takes time to obtain the result. These reasons cause the miners experience difficulty in pursuing the fisheries and animal husbandry.

Meanwhile, those who run in the brick production find it successful. The brick production improves the family economy of the miners as presented in Figure 4.

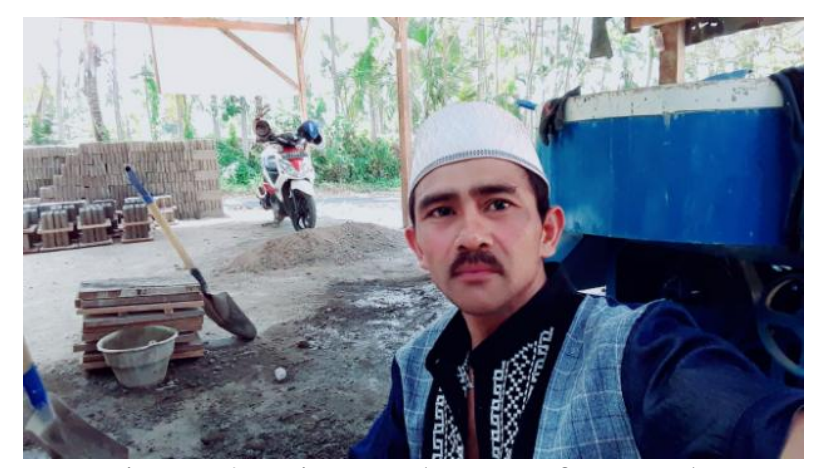

Figure 4. Miners who transform to be entrepreneurs of brick production

Overall, the process of the miners' transformation is presented in Figure 5.

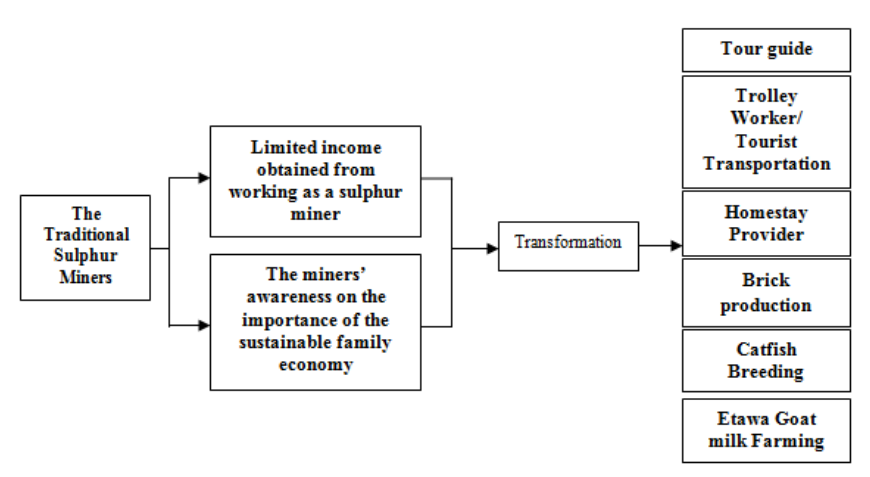

Figure 5. The Transformation Process of the Traditional Miners

\section{The Economic Sustainability of Sulphur Miners through Work Transformation}

Relying on the limited income from mining, the miners cannot meet the entire needs of the family. They only meet the first level of the basic need, such as food to eat, water to drink, and a place to live in low standards. The children cannot pursue a better education because their parents can not afford funding them up to higher school. If the condition occurs continually, the economic sustainability of the family can not be achieved. Meanwhile, the economic sustainability of the family is necessary to achieve the family 
welfare [12]. The trend of the miners' work transformation to some other opportunities leads to the economic sustainability. The sustainable family economy, as the smallest unit of economy, significantly contributes to the sustainability of the Indonesian economy at the macro economic level.

The economic sustainability upon the miners' family after the transformation is expected to improve years ahead so that: 1) they can fulfill their daily basic needs and increase in the level of well-being; 2) they can afford for the education of their children; 3) they can do saving for any unexpected need. The three aspects of the miners' need at least meet some of the indicators of sustainable development with respect to the ability of the family to fulfill [13], [14].

\section{CONCLUSION}

There are three types of miners in Ijen crater. The first miners are those who work as a Superintendent of Sulfatara; the second work in sulphur burning; and the third work as carriers of sulphur from the crater up to the sulphur burning area. The first and the second miners are those employed by $\mathrm{CN}$ Company, the only company that runs in sulphur processing in the area. Meanwhile, sulphur mining and transporting is a type of work independently carried out by the society, but the result is sold to the company.

Due to the lack of income from mining, since 2000, they have been making a transformation of work. In addition to mining, they afford to find other work, such as being tour guides, providing homestay, cultivate catfish and Etawa goat farming. The types of work, being a tour guide and a homestay provider give major contribution to their income development. The cultivating of the catfish and Etawa goat milk did not indicate outstanding results due to their lack of skills and motivation for animal husbandry.

The transformation lets the sustainability of the family life of the miners maintained. They have the opportunity to learn new things. The important thing is doing other types of work besides mining to increase their income to they can afford for both basic and secondary needs. The necessity to send the children to the higher level of education is successfully fulfilled. The fact that their children can pursue to higher education is expected that they can find better jobs or business opportunities so that they can keep the family welfare.

\section{REFERENCES}

[1] https://vsi.esdm.go.id/index.php/gunungapi/datadasar-gunungapi/522-g-ijen?star=4. Accessed on 24th January, 2015.

[2] Khoiriyah, and Harini, 2015. Valuasi Ekonomi Penambang Sumberdaya Belerang Ijen crater, Desa Tamansari, Kabupaten Banyuwangi, Provinsi Jawa Timur. Jurnal Bumi Indonesia, Vol. 4 No. 4.

[3] Fatimah, et.al, 2016, The Efforts to Increase the Incomeof Sulphur Miners through Economic Transformation in Mount Ijen Banyuwangi, Indonesia. IOSR Journal of Humanities And Social Science (IOSR-JHSS). Volume 21, Issue 10, Ver. 3

[4] Mensah, Justice, and Sandra Richart Casadevall (Reviewing editor) (2019), Sustainable development: Meaning, history, principles, pillars, and implications for human action: Literature review, Cogent Social Sciences.

[5] Azis, M., 2014. Model Pertambangan Emas Rakyat dan Pengelolaan Lingkungan Tambang di Wilayah Desa Paningkaban, Kecamatan Gumelar, Kabupaten Banyumas, Jawa Tengah. Jurnal Dinamika Rekayasa. Vol. 10 No. 1 February 2014, ISSN 1858-3075.

[6] Been, Slay, N Thelen, and V Gracia. 2012. Triple Wins For Sustainable Development: Case Studies of Sustainable Development in Pracrtice. JEPS. Vol. 5. No. 2. 2013.

[7] UNICEF. 2014. Key Findings on Families, Family Policy and the Sustainable Development Goals. Synthesis Report.

[8] [8] Miles, MB and Huberman, AM. 1992. Analisis Data Kualitatif, Buku Sumber Tentang Metode-metode Baru, Jakarta, Universitas Indonesia.

[9] Cresswell, John W. 1994. Researh Design: Qualitative and Quantitaive Approaches, Thausand Oaks: Saga Publication. 
[10] Hawkins, RL. 2005. From Self-Sufficiency to Personal and Family Sustainability: A New Paradigm for Social Policy. The Journal of Sociology \& Social Welfare: Vol. 32: Iss. 4, Article 6.

[11] Brown C., 2008. Emergent Sustainability: The Concept of Sustainable Development in a Complex World, In: Brauch H.G. et al. (eds) Globalization and Environmental Challenges. Hexagon Series on Human and Environmental Security and Peace. vol 3. Springer, Berlin, Heidelberg, Print ISBN 978-3-540-75976-8, Online ISBN 978-3-540-75977-5.

[12] Xiao, 2013. Family Economic Well-being, Book-chapter, University of Rhode Island, DOI: 10.1007/978-1-4614-3987-5_24

[13] BPS-Statistics Indonesia. 2015. Indicators of Sustainable Development. BPS Indonesia, ISSN: 2086-2814. www.bps.go.id.

[14] Amiruddin, DS. 2017. Social Adaptation of Traditional Fishing Women in Helping the Family Economic Sustainability in Binuangen Banten. The International Journal of Social Sciences and Humanities Invention. Vol. 4, No. 9. Pp. 3958-3965. https://doi.org/10.18535/ijsshi/v4i9.10 